\title{
Analysis of possible shipbuilding application of friction stir welding (FSW) method to joining elements made of AIZn5Mg1 alloy
}

\author{
Krzysztof Dudzik, M. Sc. \\ Mirosław Czechowski, Ph. D. \\ Gdynia Maritime University
}

\begin{abstract}
In industrial practice the welding of Al-alloys is usually performed under pure argon shielding by means of MIG or TIG methods. In recent years new joining techniques such as friction stir welding (FSW) have appeared. Joints of EN AW-7020 T6 alloy elements welded by using FSW method have been tested. Results of static tensile tests, transverse bending tests as well as tests on stress corrosion susceptibility are presented. Parameters of friction welding (FSW) applied to joints of plates made of AlZn5Mg1[7020] alloy are given. Stress corrosion tests have been performed by using slow-strain-rate testing method (SSRT) in compliance with PN-EN ISO 7539-7 standard. The tests were conducted in air and 3.5\% NaCl water solution. The following parameters have been measured during the tests: time to failure $-T[h]$, maximum failure load $-F[N]$, fracture energy (area under stress-elongation curve) $-E\left[M J / m^{3}\right]$, relative elongation of specimen $-A_{10}[\%]$, maximum tensile stress $-R[M P a]$, as well as percentage reduction of area $-Z[\%]$. On the basis of the obtained test results it was concluded that the joints welded by means of FSW method show good resistance to stress corrosion at satsifactory strength properties, which indicates that application of friction welding by using FSW method in shipbuilding industry is purposeful.
\end{abstract}

Keywords: aluminium alloys, friction stir welding, stress corrosion cracking

\section{INTRODUCTION}

Aluminium alloys are materials which find worldwide industrial applications, inluding shipbuilding. Their application to ship hull structures is increasing as the alloys make it possible to lower significantly mass of structures as compared with that of steel structures. By using Al-alloys lowering the mass by about $50 \%$ can be obtained, which makes it possible to increase ship buoyancy, or at maintained buoyancy to increase its load carrying capacity or speed, as well as to improve its stability. For the reasons Al-alloys are used a.o. for construction of ship hull and superstructures. Among weldable Al-alloys suitable to plastic working the group of Al-Mg alloys (of 5xxx- series) of good weldability and relatively good service conditions are still the most popular. Their relative insuspectibility to layer and stress corrosion is advantageous, and their disadvantage is low strength of welded joints of elements made of them, not exceeding $300 \mathrm{MPa}$. In the1990s Al-Zn-Mg alloys (of 7xxx series) attracted high interest. They are characteristic of higher strength properties as compared with those of Al-Mg alloys. Susceptibility to layer and stress corrosion is a disadvantage of Al-Zn-Mg alloys. Multi-year research has revealed that thermal working, chemical composition and welding technology (welding method, kind of added materials and type of joint) are a.o. responsible for stress corrosion susceptibility of the alloys $[1 \div 7]$. Practically all welded joints made of alloys of this group by means of traditional MIG or TIG methods do not show sufficient resistance to stress or layer corrosion, hence only $\mathrm{Al}-\mathrm{Mg}$ alloys of $5 \mathrm{xxx}$ - series are the only materials applicable to hull structures of light-weight ships.

The Friction Stir Welding (FSW) method may appear an alternative to traditional welding methods such as MIG or TIG methods. In the method a tool fitted with rotary mandrel located in the place of welding the pressed-down plates is used to heat and plastify the material. After putting the mandrel-fitted tool into rotation, friction heating and plastifying the plate material in its direct vicinity occurs, and slow sliding the entire system follows along contact line (Fig. 1). As it is a solidstate welding method, i.e. that below melting point of material, strength properties of joints obtained by the method can be better than those obtained from arc welding techniques (MIG, TIG). Main advantage of the method is easiness of producing joints of repeatable high properties $[9,12,13]$. As in FSW method welding is performed in solid state a far smaller amount of heat is delivered to welded materials than that in the case of traditional welding. This greatly limits range of heat-affected zone. Tests on Al-Zn-Mg alloys joined by using MIG and TIG methods, under action of agressive sea environment, revealed their low resistance to stress and layer corrosion which occurred just in heat-affected zone [8].

Possible application, in shibuilding industry, of the alloy of $7 \mathrm{xxx}$-series of greater strength than the commonly used 
alloys of 5xxx-series, depends on finding a welding method which could ensure its corrosion resistance in sea water. This work has been aimed at determination of possible application, in shipbuilding industry, of a new welding technology for joining elements of 7020 alloy with the use of FSW method. The analysis has been conducted on the basis of results obtained from research on susceptibility to stress corrosion in artificial sea water of strength characteristics of joints made of AlZn5Mg1 (AW-7020) alloy, welded with the use of FSW method, as well as results of bending tests.

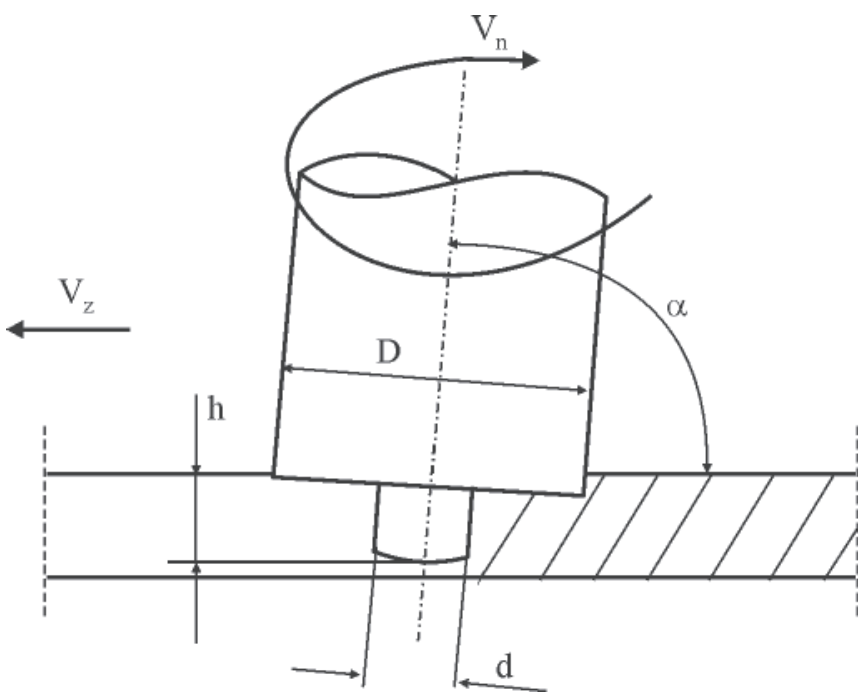

Fig. 1. Schematic diagram of FSW method [9]: D-tool diameter, $\boldsymbol{d}$ - pin diameter, $\boldsymbol{h}$ - pin length, $\boldsymbol{\alpha}$-angle of tool deflection, $\boldsymbol{V}_{\boldsymbol{n}}-$ Mandrel's rotary speed, $\boldsymbol{V}_{z}-$ Welding speed

\section{TESTING METHOD}

To the tests the plates of the thickness $\mathrm{g}=10 \mathrm{~mm}$, made of EN AW-7020 Al- alloy saturated and aged (i.e.in T6 state), were used. Chemical composition of the 7020 Al- alloy is presented in Tab. 1.

Tab. 1. Chemical composition of 7020 Al-alloy

\begin{tabular}{|c|c|c|c|c|c|c|c|c|c|}
\hline \multicolumn{10}{|c|}{ Chemical composition [ \%] } \\
\hline $\mathrm{Si}$ & $\mathrm{Fe}$ & $\mathrm{Cu}$ & $\mathrm{Mn}$ & $\mathrm{Mg}$ & $\mathrm{Cr}$ & $\mathrm{Zn}$ & $\mathrm{Ti}$ & $\mathrm{Zr}$ & $\mathrm{Al}$ \\
\hline 0.30 & 0.35 & 0.10 & 0.24 & 1.30 & 0.14 & 4.70 & 0.08 & 0.07 & $\begin{array}{c}\text { the } \\
\text { rest }\end{array}$ \\
\hline
\end{tabular}

Joints were butt ones two-sided welded by using FSW method. The applied parameters of friction stir welding (FSW), i.e. that associated with weld material stirring (see Fig. 1), are given in Tab. 2.

Tab. 2. FSW parameters applied to welding of $7020 \mathrm{Al}$ - alloy plates

\begin{tabular}{|c|c|c|c|c|c|}
\hline $\begin{array}{c}\mathbf{D} \\
{[\mathbf{m m}]}\end{array}$ & $\begin{array}{c}\mathbf{d} \\
{[\mathbf{m m}]}\end{array}$ & $\begin{array}{c}\mathbf{h} \\
{[\mathbf{m m}]}\end{array}$ & $\alpha\left[^{\circ}\right]$ & $\begin{array}{c}\text { Mandrel's } \\
\text { rotary speed } \\
\mathbf{V}_{\mathbf{n}} \\
{[\mathbf{r p m}]}\end{array}$ & $\begin{array}{c}\text { Welding } \\
\text { speed } \\
\mathbf{V}_{\mathbf{z}} \\
{[\mathbf{m m} / \mathbf{m i n}]}\end{array}$ \\
\hline 25 & 10 & 5.8 & 88.5 & 450 & 180 \\
\hline
\end{tabular}

The stress corrosion tests were conducted with the use of SSRT (Slow Strain Rate Testing) method in compliance with PN-EN ISO 7539-7 standard [12]. The tests were carried out on a special measurement stand which made it possible to stretch specimens at strain rate in the range from $10^{-3}$ to $10^{-7}$ $\mathrm{s}^{-1}$ in corrosive environment.

The following parameters : the relative elongation of specimen in the instant of its failure $\mathrm{A}_{10}[\%]$, the maximum force $\mathrm{F}_{\text {max }}[\mathrm{kN}]$, the maximum stress $\mathrm{R}_{\text {max }}[\mathrm{MPa}]$, the relative fracture energy $E\left[\mathrm{MJ} / \mathrm{m}^{3}\right]$ (area under stress-elongation curve), the reduction of area in the instant of specimen fracture Z [\%], duration time till the specimen failure $\mathrm{T}[\mathrm{h}]$, were recorded with the aid of computer during the tests or just after its termination.

The tests were performed on smooth cylindrical specimens free of notch. They were conducted in artificial sea water (acc. PN-66/C-06502 standard) of $+20^{\circ} \mathrm{C}$ temperature, as well as in a neutral environment - dry air, at the low strain rate $\dot{\varepsilon}=1.6 \mathrm{x}$ $10^{-6} \mathrm{~s}^{-1}$, up to complete failure of specimen. Prior to exposition the specimens were polished and degreased.

\section{TEST RESULTS}

The results obtained from the static tensile test of AW7020 alloy and its FSW method -welded joints, conducted on flat specimens (acc. EN 895:1995 standard), are presented in Tab. 3.

Tab. 3. Mechanical properties of the $A W-7020$ alloy native material and its FSW method - welded joints (average value from two or four specimens)

\begin{tabular}{|c|c|c|c|}
\hline Material & $\begin{array}{c}\text { UTS } \\
{[\mathbf{M P a}]}\end{array}$ & $\begin{array}{c}\text { YS } \\
{[\mathbf{M P a}]}\end{array}$ & $\begin{array}{c}\text { EL } \\
{[\%]}\end{array}$ \\
\hline 7020/ native material & 373 & 317 & 14.2 \\
\hline $7020 / \mathrm{FSW}$ & 367 & 314 & 13.8 \\
\hline $7020 / \mathrm{MIG}$ & 315 & 283 & 8.2 \\
\hline
\end{tabular}

UTS - Ultimate Tensile Strength, YS - Yield Stress, EL - Elongation

Joints of 7020 Al-alloy welded by using FSW method were subjected to the bending test in compliance with PN-EN 910:1999 standard. Flat specimens were used to the test in which bending mandrel of the diameter $\mathrm{D}=60 \mathrm{~mm}$ (sixfold specimen thickness) was applied. During the test no cracks were recorded up to $180^{\circ}$ bending angle, which fulfils requirements of classification institutions. A view of specimens after bending tests is given in Fig. 2.

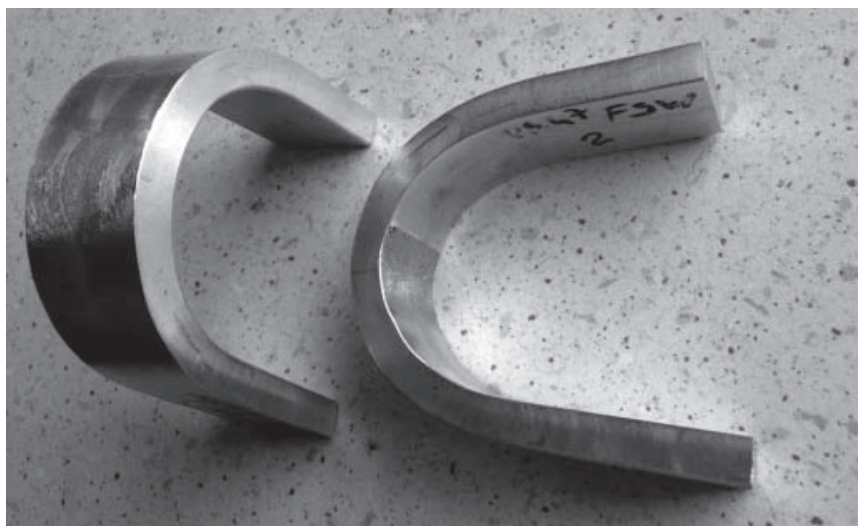

Fig. 2. A view of FSWmethod-welded specimens after bending tests

Results of the SSR tests conducted on smooth specimens in air (marked , pow.") as well as in artificial sea water (marked „NaCl"), are presented for particular measured parameters (average values from $4 \div 5$ measurements) in Tab. 4 .

Fractographic examinations of welded joints made of Al$\mathrm{Zn}-\mathrm{Mg}$ alloy were conducted on fractures achieved during the SSRT tests. Analysis of fracture surface of examined specimens was performed with the use of an XL30 Philips scanning electronic microscope (SEM). During the SSR tests the specimens formed of joints welded by using FSW method were tested till the fracture which appeared due to shear in 
Tab. 4. Slow strain rate test results

\begin{tabular}{|c|c|c|c|c|c|}
\hline Material & Environment & $\begin{array}{c}\text { Elongation } \\
\mathbf{A}_{\mathbf{1 0}}[\mathbf{\%}]\end{array}$ & $\begin{array}{c}\text { Reduction-of- } \\
\text { area } \\
\mathbf{Z}[\%]\end{array}$ & $\begin{array}{c}\text { Fracture } \\
\text { energy } \\
\mathbf{E}\left[\mathbf{M J} / \mathbf{m}^{3}\right]\end{array}$ & $\begin{array}{c}\text { Time-to- } \\
\text { failure } \\
\mathbf{T}[\mathbf{h}]\end{array}$ \\
\hline 7020 & air & 8.77 & 48.3 & 26.87 & 12.45 \\
\hline 7020 & $\mathrm{NaCl}$ & 8.77 & 45.8 & 27.1 & 12.04 \\
\hline $7020 / \mathrm{FSW}$ & air & 7.32 & 48.65 & 19.32 & 9.86 \\
\hline $7020 / \mathrm{FSW}$ & $\mathrm{NaCl}$ & 7.12 & 48.8 & 19.17 & 9.53 \\
\hline
\end{tabular}

their native material. The examinations demonstrated that material decohesion was running through cristals and had plastic character (Fig. 3).
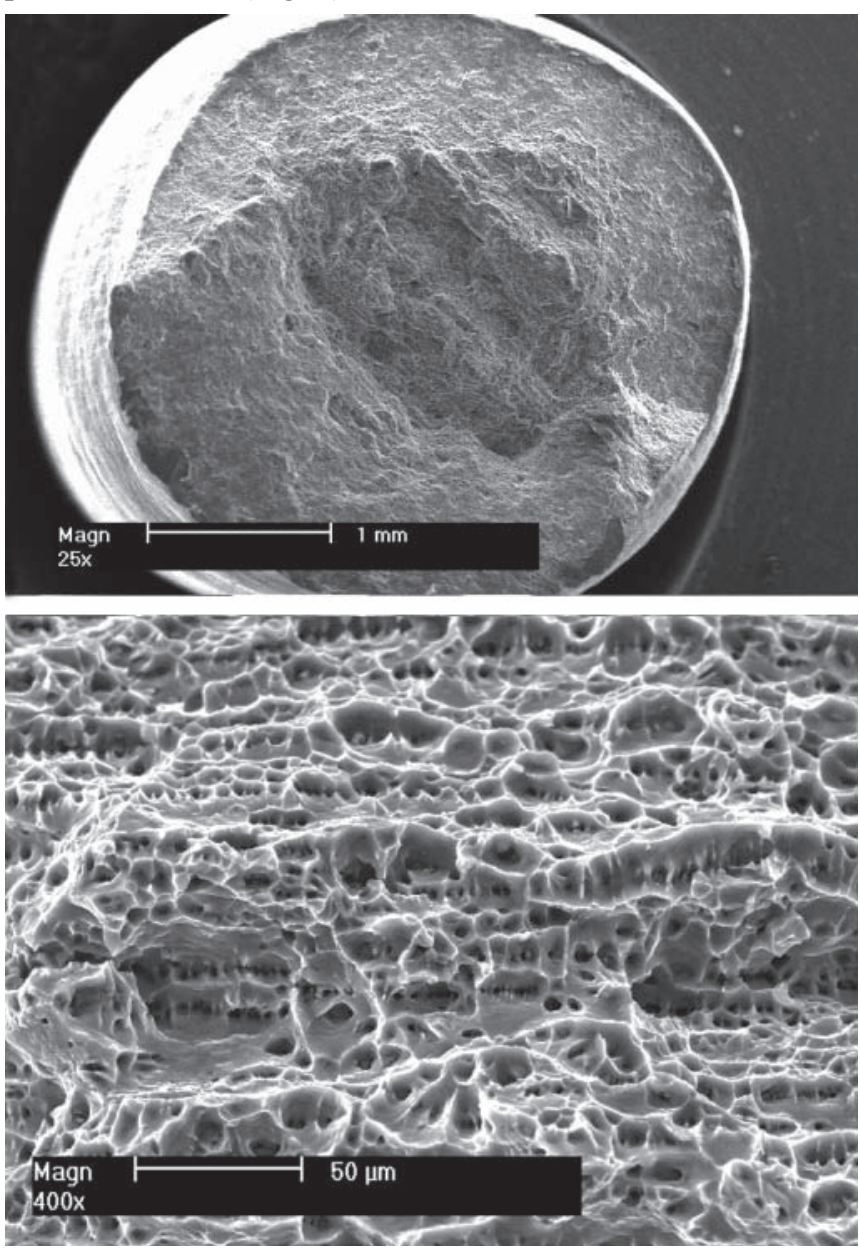

Fig. 3. Fracture of $A W-7020$ alloy joint welded by FSW, achieved during SSR test

\section{RECAPITULATION}

Investigations of mechanical properties demonstrated that strength properties of 7020 alloy welded by using FSW method are better as compared with those of MIG - welded joints of 7020 alloy and AlMg4.5Mn0.7 (5083) alloy presently most used in shipbuilding industry [7]. Such weld is free of typical defects characteristic for arc welding, e.g. gas pores or lack of weld penetration. It was confirmed by bending tests where no fractures were found after bending by $180^{\circ}$ angle.

On the basis of the obtained test results it can be stated that the friction-stir-welded $\mathrm{AlZn} 5 \mathrm{Mg} 1$ alloy (by using FSW method) is resistant to stress corrosion in sea water. Values of particular measured parameters of friction-stir-welded joints, obtained in air and artificial sea water, do not differ much to each other, respectively (Tab. 4). Relative elongation of FSW method- welded 7020 alloy specimens stretched in artificial sea water, was lower on average by only $2.7 \%$ as compared with that of such specimens tested in air. Even lower percentage decrease was obtained from the measurements of the relative reduction of area and relative fracture energy $(0.77 \%)$.

High strength of FSW method - welded joints is confirmed by location of fracture in tested specimens. During the SSR tests cracks appeared beyond weld in their native material. It concerns both the specimens exposed in air and artificial sea water. Specimens subjected to the static tensile test cracked in a similar way. In this case cracks were also located beyond weld in native material.

Summing up, it can be stated that application of the FSW method to welding Al- alloys in shipbuilding industry, seems purposeful. The most important merits of the FSW method are the following :

- the possible welding of butt and overlap joints

- good mechanical properties of welds

- minor welding deformations of elements

- lack of gas pores and cracks in welds

- lack of a shielding gas

- the possible single-run welding of material of up to $15 \mathrm{~mm}$ in thickness

- the possible obtaining of repeatable high quality of welds in all positions.

Friction welding by using FSW method has been presently applied in many high-developed industrial countries. It is used in shipbuilding, railway engineering, motor and aircraft industries $[1,14]$.

\section{CONCLUSIONS}

From the performed investigations the following conclusions can be drawn:

- Joints of ENAW-7020 T6 alloy welded by means of the new, FSW method, show higher strength properties as compared with those of joints welded with the use of the traditional method MIG.

- Joints of EN AW-7020 T6 alloy welded by means of the FSW method, show low susceptibility to stress corrosion, determined during the slow-strain-rate test (SSRT).

- AW-7020 alloy can be applied to ship structures welded with the use of FSW method.

\section{BIBLIOGRAPHY}

1. Anderson T.: New developments within the Aluminium Shipbuilding Industry, Svetsaren, no.1, Vol. 58, 2003.

2. Bugłacki H.: Influence of welding technology on resistance to corrosion of Al-Zn-Mg alloys (in Polish). International Conference on Environmental Degradation of Engineering Materials, Gdansk University of Technology, Jurata, 1999

3. Cudny K., Puchaczewski N.: Metal alloys for ship hull structures (in Polish). Gdansk University of Technology, Gdańsk, 1995 
4. Czechowski M.: Research on effect of electrochemical polarization and thermal treatment on stress cracking of Al$\mathrm{Zn}-\mathrm{Mg}$ alloys (in Polish). Zeszyty Naukowe WSM w Gdyni (Scientific Bulletins of Gdynia Maritime Academy), No. 30, Gdynia, 1996

5. Czechowski M.: Effect of anodic polarization on stress corrosion cracking of some aluminium alloys. Advances in Materials Science, no. 1(11), Vol. 7, 2007

6. Czechowski M.: Optimum methods of welding Al-Mg alloys in the aspect of their resistance to stress corrosion cracking (in Polish). Materiały i Technologie (Materials and Technologies), Gdansk University of Technology, no. 3 (3), Gdańsk, 2005

7. Czechowski M.: Properties of butt welds in Al-Mg alloy plates welded by using different methods (in Polish). Materiały i Technologie (Materials and Technologies), Gdansk University of Technology, no. 1(1), Gdańsk, 2003

8. Czechowski M., Chrzanowski J., Zieliński A.: Stress corrosion cracking in Al-alloy welded joints (in Polish). Materials of II Pomorska Konferencja Naukowa - Inżynieria Materiałowa 2001 (2nd Pomeranian Scientific Conference on Materials Engineering), Gdansk University of Technology, Sobieszewo, 2001

9. Czechowski M., Pietras A., Zadroga L.: Properties of Al-alloys of 5000 series friction- welded by using a new, FSW technique (in Polish). Inżynieria Materiałowa, no. 6/2003
10.Czechowski M., Zieliński A.: Effect of cathodic polarization on failure and degradation of mechanical properties of some aluminium alloys. Scripta Metallurgy Materials, Vol. 30, 1994

11.Czechowski M., Zieliński A., Cudny K.: Effect of chemical composition and thermal treatment on stress corrosion cracking of aluminium alloys. Conference on Corrosion-Deformation Interactions, Fontainebleau, 1991

12.Lahti K.: FSW-possibilities in shipbuilding, Svetsaren, No.1,Vol. 58, 2003

13.Nicholas E., D., Kalle D., S.: Process of friction welding with weld material stirring is already 10 years old (in Polish). Biuletyn Instytutu Spawalnictwa (Bulletin of Welding Institute), no. $3 / 2001$

\section{CONTACT WITH THE AUTHORS}

Krzysztof Dudzik, M.Sc.

Mirosław Czechowski, Ph.D.

Faculty of Marine Engineering

Gdynia Maritime University,

Morska 81-87

81-225 Gdynia, POLAND

e-mail: krys-r6@wp.pl,czecho@am.gdynia.pl 